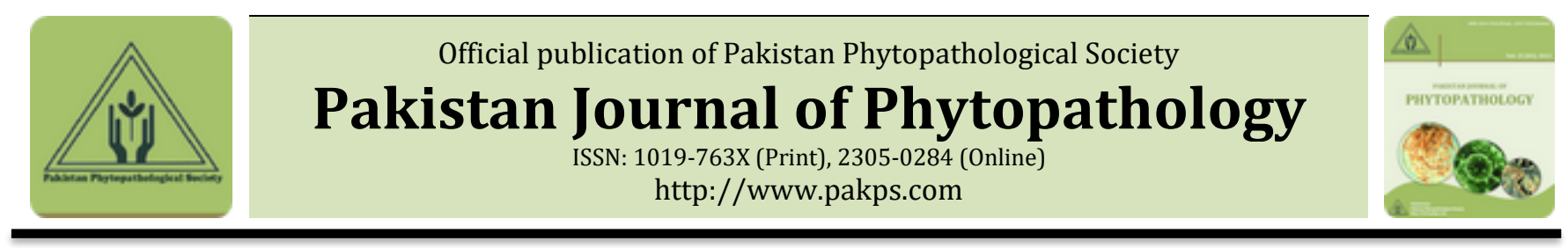

\title{
IMPACT OF IMPROVED DNA EXTRACTION METHOD FROM CITRUS LEAVES MIDRIB AND PCR FOR THE DETECTION OF CITRUS GREENING (CANDIDATUS LIBERIBACTER)
}

\author{
aMuhammad Nauman, aUmmad U. D. Umar, aSyed A. H. Naqvi*, aAteeq U.Rehman, bMuhammad T. Malik, \\ cMuhammad Shahid, aMuhammad Akbar, aMuhammad Umair \\ a Department of Plant Pathology, Faculty of Agricultural Sciences and Technology, Bahauddin Zakariya University, \\ Multan, Punjab, Pakistran. \\ b Mango Research Institute, Plant Protection Section, Old Shuja-Abad, Road, Multan, Punjab, Pakistan. \\ c Plant Pathology Research Institute, Ayub Agriculture Research Institute, Faisalabad., Punjab, Pakistan.
}

\section{A B S T R A C T}

Citrus greening/ yellow shoot disease/ HLB, caused by Candidatus liberibacter asiaticus, showing mosaic/ mottling pattern on leaves, stunting of plants, de-shape, pre-mature fruit drop and yellowing of reticulate venation as characteristic symptoms, is the most concerned disease prevailing in citrus groves of Punjab, Pakistan. For the detection of pathogen and downstream studies, a high-quality DNA is required. In citrus, due to the variety of species, different age groups in plants, thick waxy cuticle of leaves, high production of phenolics, polysaccharides and other compounds, it is very difficult to extract good quality DNA from leaves and especially from main midrib where the fastidious bacterium is residing. CTAB and SDS are two devised methods for the extraction of total genomic DNA from citrus leaves while the current research suggests some modified protocols for the detection of DNA from infected/ healthy samples. 100mg leaf midrib sample was crushed in liquid nitrogen, homogenized in $500 \mu \mathrm{CTAB}$, incubated at $60^{\circ} \mathrm{C}$ in water bath for 45 minutes, centrifuged at $12000 \mathrm{rpm}$ for 5 minutes, supernatant was transferred to new tube and $5 \mu$ RNase-A was added, incubated at $37^{\circ} \mathrm{C}$ for 20 minutes. Equal volume of chloroform/ isoamyl alcohol (24:1) was added, vortexed for 5 minutes, centrifuged for 2 minutes at $12000 \mathrm{rpm}$ for phase separation and upper phase was transferred to new tube where $500 \mu \mathrm{l}$ of chilling isopropanol was added, kept at $-20^{\circ} \mathrm{C}$ for 15 minutes, centrifuged at $12000 \mathrm{rpm}$, pallet was washed twice with $70 \%$ ethanol. CTAB method was modified by increasing the incubation time i.e., 45 minutes for cell lysis in water bath for determination the variation in quality of DNA and the amount of beta mercaptethanol was also doubled from the normal one. Modified protocols have been proved excellent for the extortion of total genomic DNA from citrus. In SDS, addition of TE buffer, RNAase, Isoamylalcohol: Chloroform (24:1) along with 20\% SDS and 2M Sodium Acetate gave high quality DNA from citrus leaves. Hence, DNA was extracted by four different ways but the modified CTAB and SDS methods gave improved quality DNA as confirmed by its quantification through nanophotometer. The DNA was quantified by nanophotometer and presence was observed on gel documentation apparatus. Hence, DNA was found suitable for PCR and RFLP analysis and long-term storage on $-80{ }^{\circ} \mathrm{C}$.

Keywords: Citrus greening, CTAB and SDS Extraction Protocol, Fastidious bacteria, PCR,

\section{INTRODUCTION}

Citrus huanglongbing (HLB), also known as citrus greening disease is major devastating disease (Deng et

Submitted: April 18, 2021

Revised: May 25, 2021

Accepted for Publication: May 25, 2021

* Corresponding Author:

Email: atifhasanshah@hotmail.com

(C) 2021 Pak. J. Phytopathol. All rights reserved. al., 2016) was detected for very first time in United States (Eveland \& Brown, 2019) and have greatest biotic threat to citrus production globally. The disease has long been endemic form only in Arabian Peninsula, Subcontinent, Asia, Mascarene islands and Africa (Chung \& Brlansky, 2006). This disease is associated with gram-negative bacteria which belongs to subdivision of proteobacteria (Garnier \& Bové, 1983) is constantly associated with the disease but this bacteria cannot be isolated on artificial 
media, so the name of the organism has provisional ('Candidatus') status in nomenclature and Koch's postulates for this pathogen and disease can never be fulfilled. The disease is established by three forms of HLB bacteria: 'Ca. Liberi-bacter asiaticus', 'Ca. L. africanus', and 'Ca. L. americanus'. The disease can be dispersing rapidly Table 1. Various pathovars of C. liberibacter

\begin{tabular}{|c|c|c|c|c|c|}
\hline Sr. No. & Type & \multicolumn{2}{|l|}{ Insect Vector } & \multicolumn{2}{|c|}{ Tolerance of heat } \\
\hline 1. & Asian & \multicolumn{2}{|c|}{ Diaphorina citri (psyllid)* } & \multicolumn{2}{|c|}{ Tolerant (Yes) } \\
\hline 2. & African & \multicolumn{2}{|c|}{ Trioza erytreaae (psyllid)* } & \multicolumn{2}{|c|}{ Sensitive (No) } \\
\hline 3. & American & \multicolumn{2}{|c|}{ Diaphorina citri (psyllid) } & \multicolumn{2}{|c|}{ Tolerant (Yes) } \\
\hline \multicolumn{6}{|c|}{ Table 2. Various names of the (Huanglongbing) HLB called upon throughout the world. } \\
\hline $\begin{array}{l}\text { Sr. } \\
\text { No. }\end{array}$ & Continent & Country & Loc & & Reference \\
\hline 1. & Asia & China & $\begin{array}{l}\mathrm{Hau} \\
\text { bra }\end{array}$ & & (Gottwald et al., 1989) \\
\hline 2. & Asia (South East) & Philippines & Mot & & (Garnier \& Bové, 1993) \\
\hline 3. & Asia & India & Die & & (Fraser \& Singh, 1968) \\
\hline 4. & East Asia & Taiwan & Likı & & (Garnier \& Bové, 1993) \\
\hline 5. & Asia (South East) & Indonesia & Veir & & (Bové et al., 2000) \\
\hline 6. & Africa & South Africa & Gre & & (Planet et al., 1995) \\
\hline 7. & Asia & Pakistan & Gre & & (Yaqub et al., 2017) \\
\hline 8. & North America & USA (Florida) & HLE & & (Bové, 2006) \\
\hline
\end{tabular}

*Out of the cited facts HLB has become the official name of this disease because it was first used in the literature and in the history.

The tree produces yellow shoots when it is completely infected. In Chinese, HLB meant "yellow shoot", so it is characteristic symptom of HLB disease. Infected fruits become lopsided, off flavored, and often contain aborted seed. Capacity of plant to produce fruit is reduced, fruit remain small and usually drop prematurely. The tree dies and declines within 2-3 years.

The bacteria penetrate through phloem vessels and attack the vascular bundles, cause the blockage of veins, and radically inhibit the nutrients and water transportation. During 1919 in China, this disease was already described. HLB was affecting and causing serious damage to citrus yield in many citrus groves in India, South Africa and South East Asia in early $20^{\text {th }}$ century. It was reported from Brazil in 2004 (Coletta-Filho et al., 2004, do Carmo Teixeira et al., 2005) and it was appeared in different localities in Florida in 2005 (Spreen et al., 2014). The HLB bacteria detected from Florida was $L$. asiaticus and from Brazil L. americanus was found associated with HLB. The occurrence of greening disease in Florida is supposed to have extremely affected and reduced the citrus yield. After realizing the serious by activity of vector psyllids Diaphorina citri and by the propagation of infected plant materials. The symptoms of this disease include an unparalleled mottling of the leaves, frequently the midribs of the leaves to yellow from green. Canopy of plant decline and dieback, lead to death of the whole plant. 
by Diaphorina citri while African strain in transmitted by Trioza erytreae, but both vectors are able to spread either strain of HLB. Eradicating the diseased plants after disease is detected, use of healthy planting material, biological control and use of chemical insecticides to control vector are the best ways to prevent the disease. In molecular research, isolating high-quality DNA is important for detection of certain pathogens (Fang et al., 1992).

Polysaccharide contamination is a major problem when extracting DNA from plant tissues, and melicera colloidal hyalosome infect DNA samples that are insoluble in Tris-EDTA buffer or DEPC treated water, resulting in a reduction in enzyme activity (Schlink and Reski, 2002). Several DNA extraction methods have been published for the removal of polysaccharides (Möller et al., 1992, De La Cruz et al., 1997, Porebski et al., 1997, Schlink and Reski, 2002). On the other hand, in certain woody fruit crops with high levels of polysaccharide, such as Citrus spp., protocols could only be applied to robust tissue, and the DNA isolated was not of adequate consistency to be used in PCR and RFLP tests (Porebski et al., 1997). This method is ideal for separating genomic DNA from fruit crops with high polysaccharide content, such as citrus. The aim of the current study was to compare different methods of DNA extraction in order to obtain high-quality DNA for PCR amplification and long-term storage. In light of the above, the current study aimed to compare various DNA extraction protocols for high-quality genomic DNA from the midribs of citrus leaves.

\section{MATERIALS AND METHODS}

Sampling of different citrus cultivars: The plant materials were collected from different citrus cultivars viz., including orange, mandarin, tangerine, grapefruit, pummelo, kumquat, trifoliate orange, showing the characteristic symptoms of the citrus haunglongbing and tagged in the course of surveys. Plant samples of leaves from above ground parts roots and fruit were also collected in plastic bags, kept on ice and brought to the Laboratory for the further processing.

Genomic DNA extraction of citrus through modified CTAB method : $100 \mathrm{mg}$ of leaf midrib was crushed in liquid nitrogen and homogenized in $500 \mu \mathrm{l}$ of CTAB buffer, incubated at $60^{\circ} \mathrm{C}$ in water bath for 45 minutes. After incubation, the mixture was centrifuged at $12000 \mathrm{rpm}$ for 5 minutes. The upper supernatant layer was transferred to new tube and 5 $\mu \mathrm{l}$ RNase A was added, incubated at $37^{\circ} \mathrm{C}$ for 20 minutes. An equal volume of chloroform/ isoamyl alcohol (24:1) was added, vortexed for 5 minutes. Centrifuged for 2 minutes at $12000 \mathrm{rpm}$ for separation of phases. The upper phase was transferred to new tube and $500 \mu \mathrm{l}$ of chilling isopropanol was added, kept at $-20^{\circ} \mathrm{C}$ for 15 minutes. Centrifuged at $12000 \mathrm{rpm}$. Supernatant was discarded without disturbing the DNA pallet. Pallet was washed twice with $70 \%$ ethanol for removal of salts and debris. Discard ethanol and air dried overnight. $50 \mu \mathrm{l}$ of DEPC treated water was added after 12 hours. CTAB method was modified by increasing the incubation time i.e., 45 minutes for cell lysis in water bath for determination the variation in quality of DNA. Similarly, the amount of beta mercaptethanol was also doubled from the normal one.

Genomic DNA extraction of citrus through SDS method: Leaves showing citrus greening disease were crushed in liquid nitrogen and grinded in pestle and mortar, transferred to Eppendorf tubes. Samples were centrifuged at $10,000 \mathrm{~g}$ for 5 minutes. Supernatant was discarded and $450 \mu \mathrm{L}$ TE buffer, $4 \mu \mathrm{L}$ RNase and $30 \mu \mathrm{L}$ of $20 \%$ SDS were added in each tube. The tubes were subjected to vortex and incubated at $65^{\circ} \mathrm{C}$ for 30 minutes. In each tube, $500 \mu \mathrm{L}$ Isoamylalcohol: Chloroform (24:1) was added and mixed gently. Centrifuged and upper layer was taken into new tubes and then $50 \mu \mathrm{L}$ of $2 \mathrm{M}$ Potassium Acetate was added. Centrifuged again and upper aqueous layer was drained. $500 \mu \mathrm{L}$ of chilled 2Propanol was added and again supernatant was discarded after centrifuge at $12000 \mathrm{rpm}$. Tubes were washed twice without disturbing the DNA pallet. Dried overnight and $100 \mu \mathrm{L}$ of DEPC treated water was added in each tube and subjected to Nanophotometer for determination the quality and purity of extracted DNA.

Genomic DNA extraction of citrus through modified SDS method: Mid rub tissues of citrus leaves were cut and grind by liquid nitrogen. Grinded tissue was transferred in Eppendorf tube. $800 \mu \mathrm{l}$ of extraction buffer (Tris HCL, EDTA and $\mathrm{NaCl}$ ) containing $2 \% \mathrm{v} / \mathrm{v}$ beta mercaptethanol and $2 \% \mathrm{w} / \mathrm{v}$ PVP, was added in each tube and mixed gently. The tubes were incubated at $65^{\circ} \mathrm{C}$ in water bath for 20 minutes and were gently blending for every $5 \sim 10 \mathrm{~min}$. Tubes were treated with $2 \mu \mathrm{l}$ of RNAse A and Protease K. After cooling $225 \mu \mathrm{l}$ 
Potassium acetate was added and kept on ice for 1 hour. Centrifuged at room temperature with 12000 RPM for $10 \mathrm{~min}$, supernatant was saved. Chloroform and isoamyl alcohol (24:1) was added to the supernatant and mixed. Centrifuged at 12000 RPM for 10 min and supernatant was saved again Resuspended the nuclei pellet with equal volume of frozen isopropanol. Tubes were washed twice with cold $75 \%$ ethanol. Air dried overnight and $100 \mu \mathrm{l}$ TE buffer was added in each tube.

Molequle-on kit method for the extraction of genomic DNA: Fresh leaf samples were crushed and grind in pestle and mortar, $200 \mu$ of TE buffer was added. $400 \mu \mathrm{l}$ of digestion solution was added and mixed well, $3 \mu \mathrm{l}$ of Proteinase K solution was added in each tube and incubated on water bath at $55^{\circ} \mathrm{C}$ for 5 minutes. $260 \mu \mathrm{l}$ of pure ethanol (100\%) was added and mixed gently. The homogenous mixture was shifted to molequle-on spin column placed in $2 \mathrm{ml}$ collection tube and centrifuged at $8000 \mathrm{rpm}$ for 2 minutes. The upper

Table 3. List of primers used for the detection of $C$. Liberibacter after extraction of DNA through various methods to optimize the best protocol for extraction.

\begin{tabular}{|c|c|c|c|c|}
\hline Primer & Target gene & Sequence & $\begin{array}{l}\text { Amplicon } \\
\text { Size }\end{array}$ & Reference \\
\hline $\begin{array}{l}\text { Las606 \& } \\
\text { Lss }\end{array}$ & $\begin{array}{l}\text { Las 16S } \\
\text { rDNA }\end{array}$ & $\begin{array}{l}5^{\prime} \text {-GGA GAG GTG AGT GGA ATT CCG A- } \\
3^{\prime} \\
5^{\prime} \text {-ACC CAA CAT CTA GGT AAA AAC C- } \\
3^{\prime}\end{array}$ & $500 \mathrm{bp}$ & $\begin{array}{l}\text { (Fujikawa \& Iwanami, } \\
\text { 2012) }\end{array}$ \\
\hline $0 i 1 \& 0 i 2$ & $16 \mathrm{~S}$ rDNA & $\begin{array}{l}5^{\prime} \text {-GCGCGTATGCAAGAGCGGCA-3' } \\
5^{\prime} \text {-GCCTCGCGACTTCGCAACCCAT-3' }\end{array}$ & $1160 \mathrm{bp}$ & (Jagoueix et al., 1994) \\
\hline$A 2 \& J 5$ & $16 \mathrm{~S}$ rDNA & $\begin{array}{l}\text { 5'-TATAAAGGTTGACCTTTCGAGTTT-3' } \\
\text { 5'-ACAAAAGCAGAAATAGCA }^{\text {'AGAACAA-3' }}\end{array}$ & $703 \mathrm{bp}$ & (Jagoueix et al., 1996) \\
\hline$S 3 \& S 4$ & 16S rDNA & GTAAACGATGAGTGCTAGCTGT-3' & $359 \mathrm{bp}$ & (Hong et al., 2019) \\
\hline
\end{tabular}

For conventional method 10X PCR buffer was taken in $5 \mu \mathrm{l}$, DNTPs $0.5 \mu \mathrm{l}, \mathrm{MgCl}_{2} 1.7 \mu \mathrm{l}$, Taq DNA polymerase $0.3 \mu \mathrm{l}$, Primer F and Primer R were taken in $2 \mu \mathrm{l}, \mathrm{dH}_{2} \mathrm{O}$ 14.8 and DNA template was $1 \mu \mathrm{l}$. For Master mix reaction, master mix was taken in $12.5 \mu \mathrm{l}, \mathrm{dH}_{2} \mathrm{O} 9.5 \mu \mathrm{l}$, Primer F and Primer R were used in $2 \mu \mathrm{l}$ and DNA was used in same quantity as taken in conventional method. All Samples were amplified for 30 cycles using My cycler. Denaturation took 30 seconds at $94^{\circ} \mathrm{C}$, annealing took 30 seconds at $55-60^{\circ} \mathrm{C}$, extension took 60 seconds at $72^{\circ} \mathrm{C}$, and final extension took 10 minutes at $72^{\circ} \mathrm{C}$. Amplifications were observed on a $1 \%$ agarose gel containing ethidium bromide and observed under ultraviolet UV lights.

RESULTS layer was drained and $500 \mu \mathrm{l}$ of wash solution was added, again centrifuged and this step was repeated. Again, discard the supernatant and spin at $8000 \mathrm{rpm}$ to remove the debris of wash solution. The molequle-on column tube was placed on clean Eppendorf tube and 30 $\mu$ of elution buffer was added to middle part of membrane in column. Tubes were incubated at room temperature 2-3 minutes to obtain high quality DNA. To Elute genomic DNA from column, tubes were subjected to centrifuge at $8000 \mathrm{rpm}$ for 5 minutes. Purified DNA was kept at -20 .

PCR detection of HLB: The PCR amplification was done by My Cycler (Bio Rad) by using four set of primers i.e. A2 F\& J5 R, Oi1 F \& Oi2 R, Laas \& Lass, S3 \& S4. PCR amplification was performed by using DNA which was extracted by four methods. Amplification was carried out in $25 \mu \mathrm{l}$ reaction by using conventional method and Master Mix Method. 
result of this small improvement in the process. (Table 4, Fig: 1, 2, 3, 4).

Table 4. Quantification of DNA with various extraction methods through nanophotometer

\begin{tabular}{|c|c|c|c|c|c|}
\hline \multirow{2}{*}{ Varieties } & \multirow{2}{*}{ Methods } & \multirow{2}{*}{$\begin{array}{l}\text { Quantity } \\
{ }^{*} \text { Conc. }\end{array}$} & \multicolumn{2}{|c|}{ Quality } & \multirow{2}{*}{ Detection } \\
\hline & & & A260/280 & A260/230 & \\
\hline \multirow[t]{4}{*}{ Kinnow } & Modified CTAB & 61 & 2.31 & 2.36 & \\
\hline & SDS & 42 & 1.95 & 1.98 & + \\
\hline & Modified SDS & 54 & 2.19 & 2.24 & \\
\hline & KIT & 49 & 2.69 & 3.25 & + \\
\hline \multirow[t]{4}{*}{ Lemon } & Modified CTAB & 49 & 1.93 & 2.5 & \\
\hline & SDS & 39 & 1.9 & 2.01 & + \\
\hline & Modified SDS & 46 & 2.23 & 2.48 & \\
\hline & KIT & 74 & 2.04 & 2.77 & + \\
\hline \multirow[t]{4}{*}{ Grapefruit } & Modified CTAB & 67 & 1.97 & 2.65 & - \\
\hline & SDS & 41 & 1.52 & 1.97 & - \\
\hline & Modified SDS & 56 & 1.99 & 2.36 & _ \\
\hline & KIT & 77 & 2.33 & 3.75 & - \\
\hline \multirow[t]{4}{*}{ Sweet Orange } & Modified CTAB & 59 & 1.99 & 2.3 & + \\
\hline & SDS & 34 & 1.53 & 1.88 & + \\
\hline & Modified SDS & 44 & 1.96 & 2.26 & _ \\
\hline & KIT & 81 & 2.73 & 3.55 & + \\
\hline \multirow[t]{4}{*}{ Lime } & Modified CTAB & 50 & 2.32 & 2.75 & _- \\
\hline & SDS & 38 & 1.84 & 1.98 & + \\
\hline & Modified SDS & 46 & 2.19 & 3.13 & + \\
\hline & KIT & 69 & 1.99 & 2.39 & + \\
\hline
\end{tabular}

All the values and readings were taken at the factor 10 of nano photometer, ${ }^{*}$ Conc. $=$ Concentration

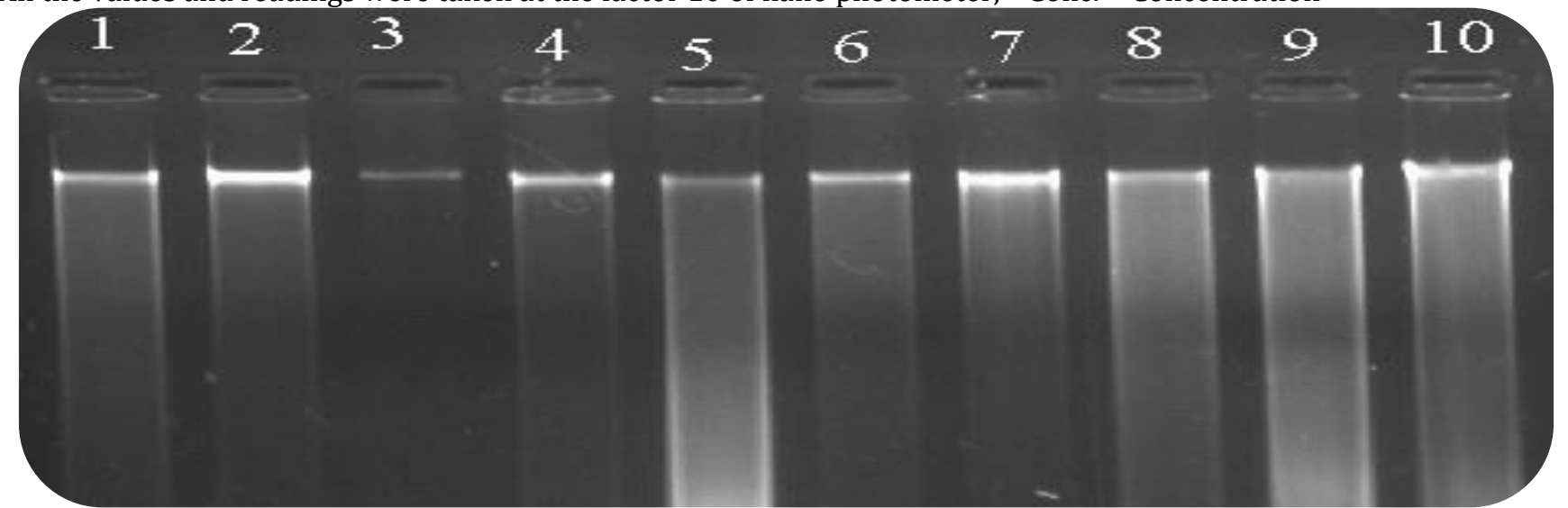

Figure 1. Extraction of DNA by CTAB method 


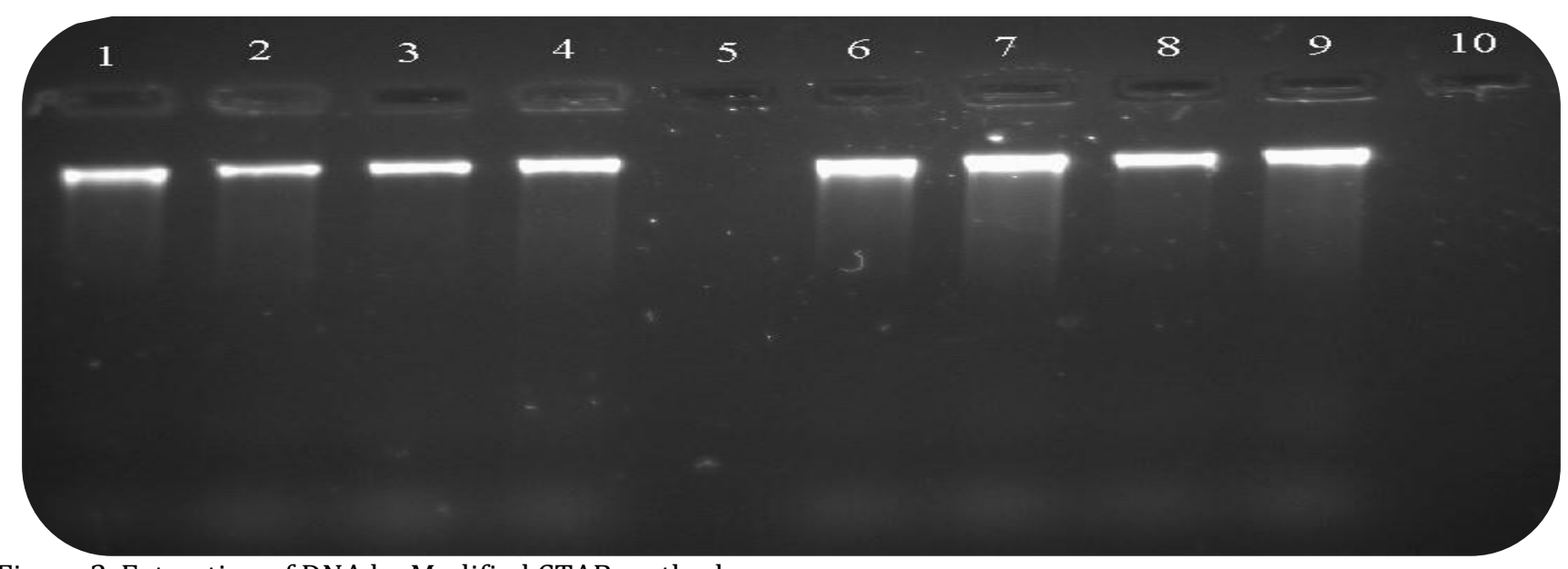

Figure 2. Extraction of DNA by Modified CTAB method

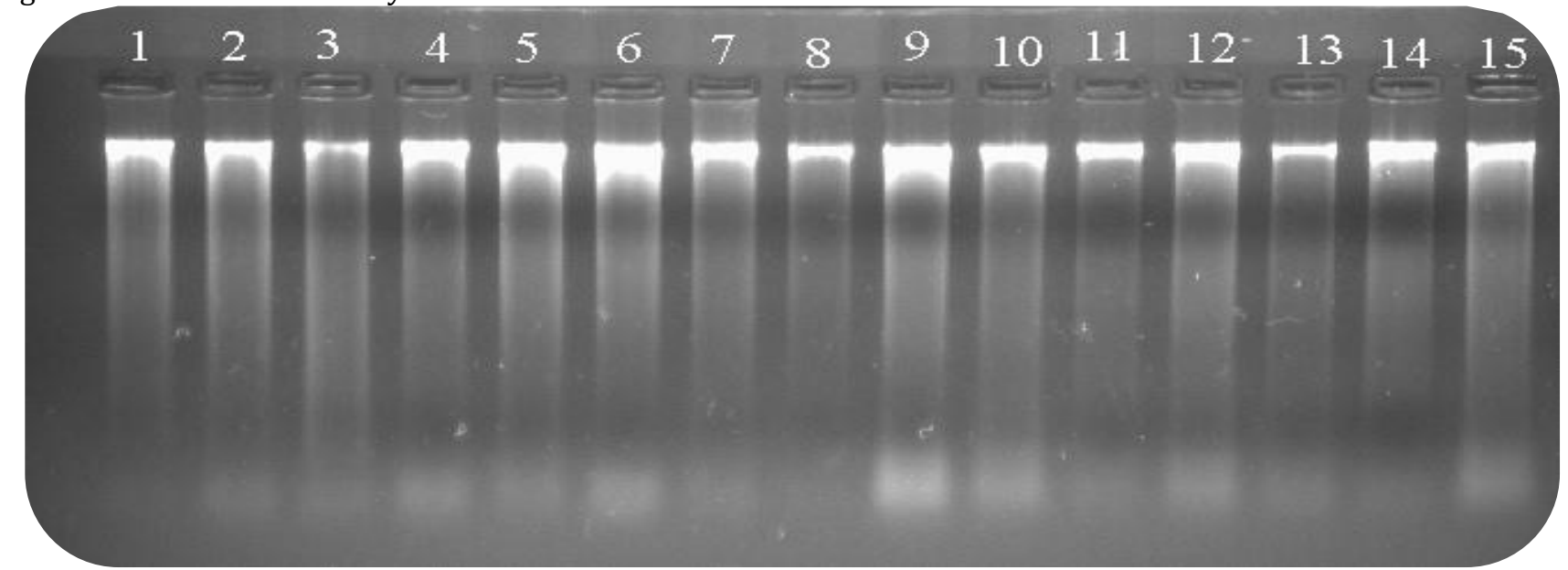

Figure 3. Extraction of DNA by SDS method

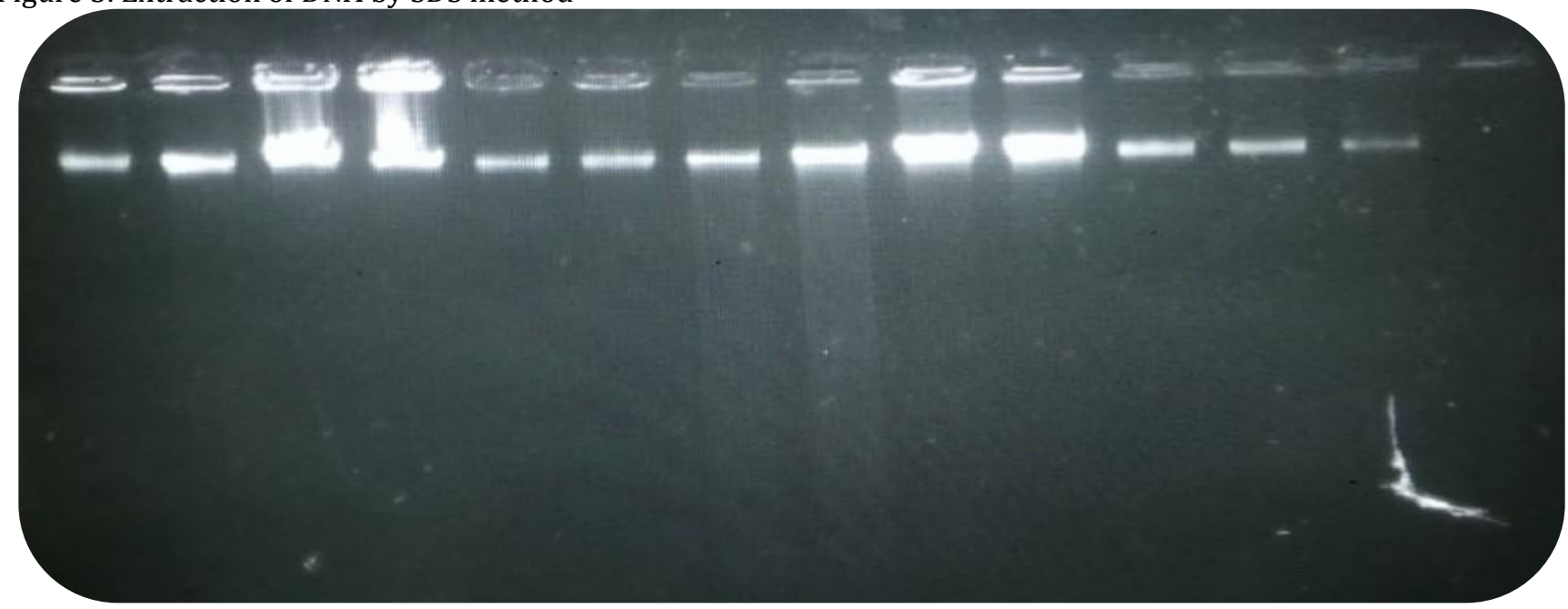

Figure 4. Extraction of DNA by Kit Method

Detection of genomic region of Candidatus liberibacter with different primers: PCR was used to detect 'Ca. L. asiaticus' from extracted DNA samples, and the sequences of established 16s rDNA regions were compared. The results of PCR detection of 'Ca. L. asiaticus' revealed that LAS primers amplified the 16s rDNA region with an estimated product size of $500 \mathrm{bp}$, while 0I1/OI2 primers amplified a 1160 bp band, and HLB specific primers A2 and J5 produced 703 bp bands. (Fig. 5, 6, 7, 8). 


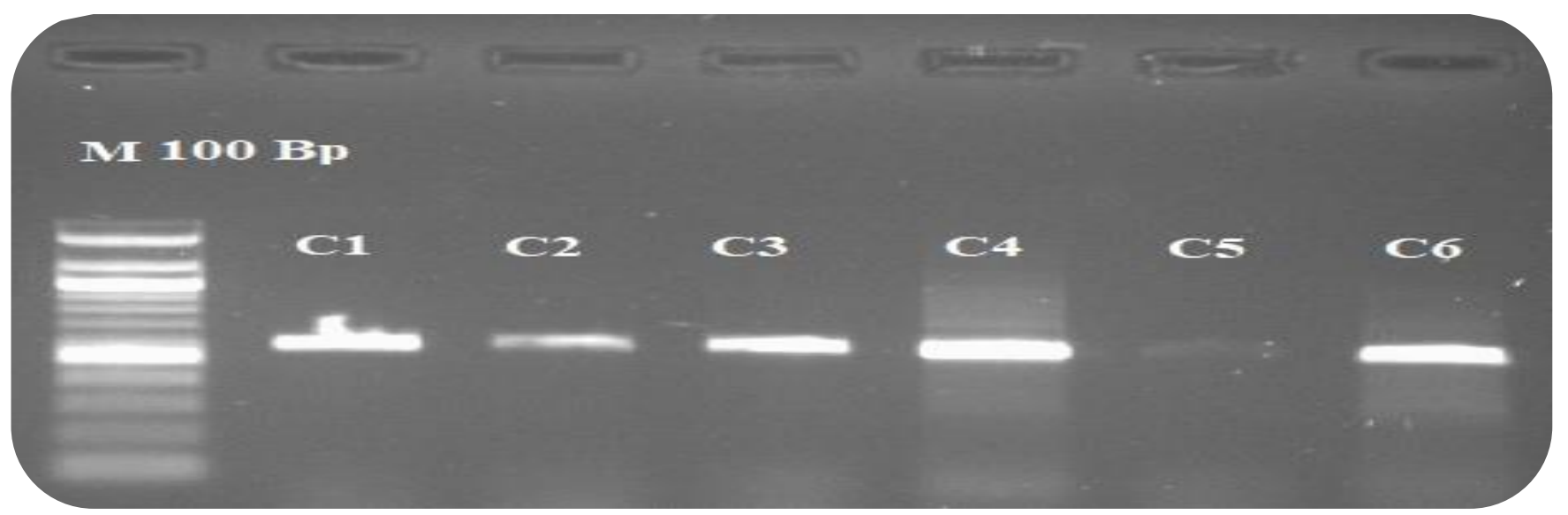

Figure 5. (1.5\%) TBE agarose gel shows band of 500bp using specific primer of HLB i.e., Lass from symptomatic leaves (Lane 1-6) Lane M: 100bp Ladder (Invitrogen) 


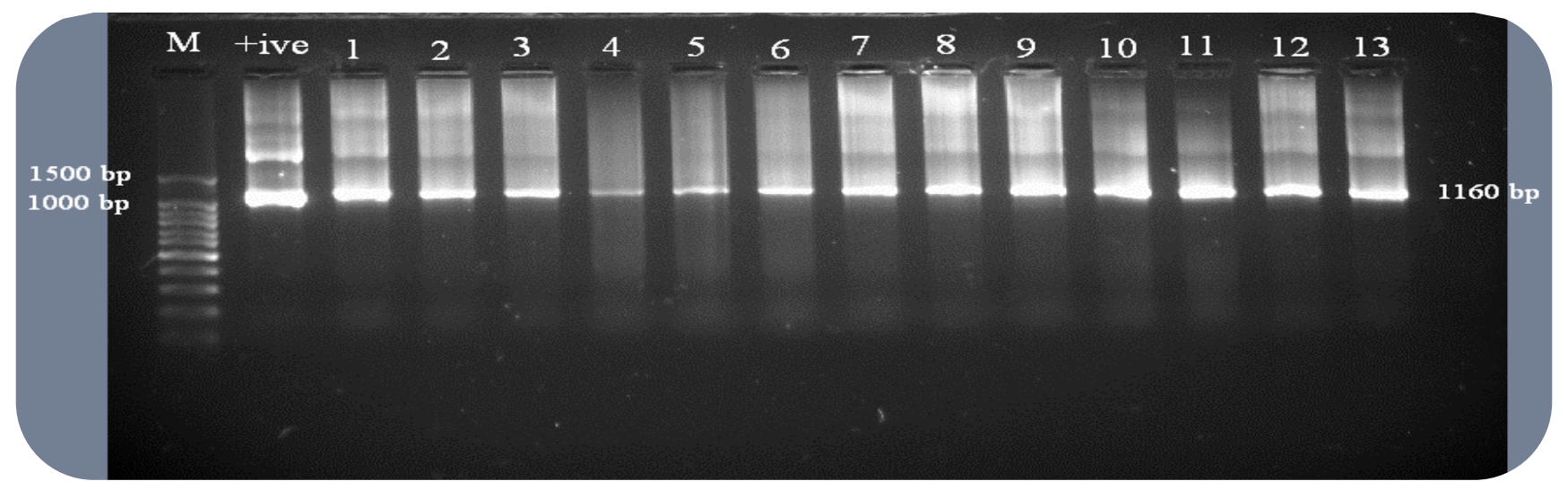

Figure 6. (1.5\%) TBE agarose gel shows band of 1160bp using specific primer of HLB i.e. OI1 \& OI2 from symptomatic leaves (Lane 1-13) Lane M: 100bp Ladder (Invitrogen) for molecular weight

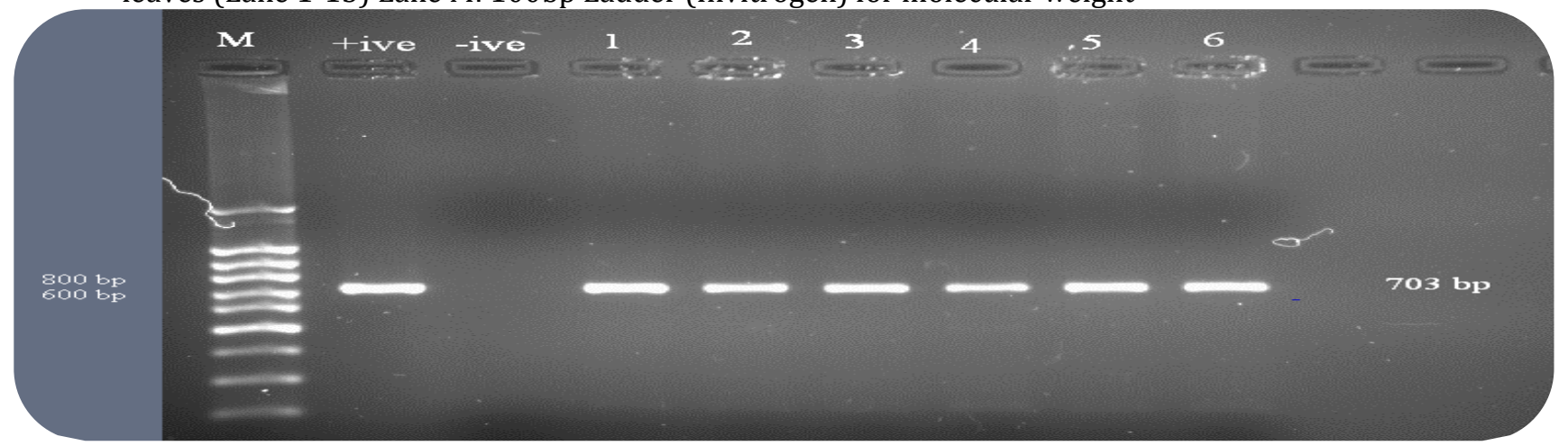

Figure 7. (1.5\%) TBE agarose gel shows band of 703bp using specific primer of HLB i.e. A2 \& J5 from symptomatic leaves (Lane 1-6) Lane M: 100bp Ladder (Invitrogen)

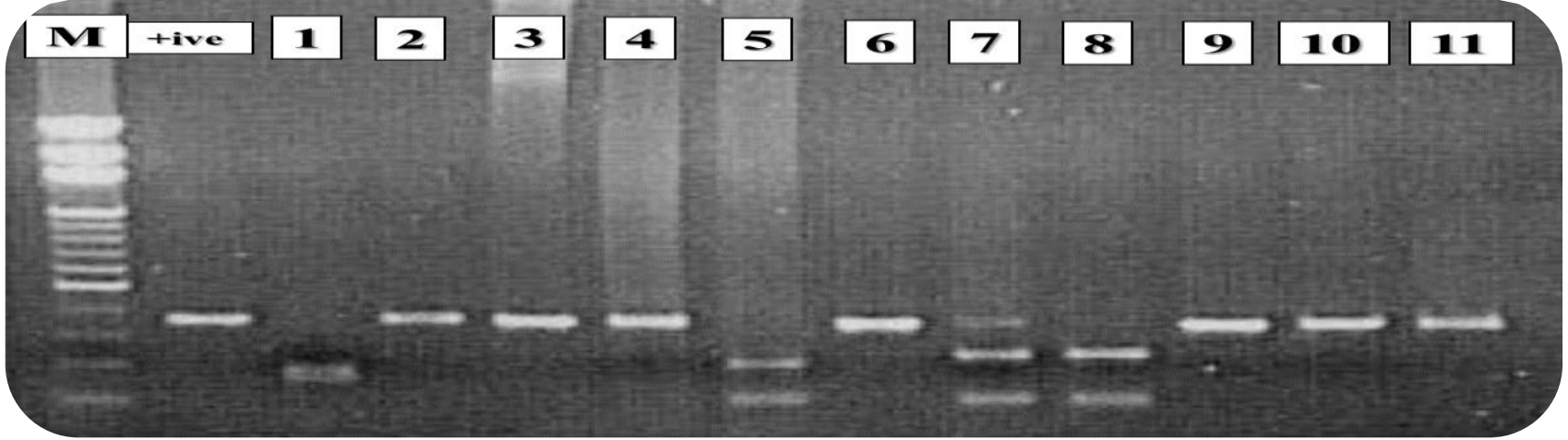

Figure 8. (1.5\%) TBE agarose gel shows band of 359bp using specific primer of HLB i.e., S3 and S4 from symptomatic leaves (Lane 1-11) Lane M: 100bp Ladder (Invitrogen)

\section{DISCUSSION}

Citrus greening diseases is of high importance for citrus industry all over the world and especially for Pakistan where this fruit ranked $2^{\text {nd }}$ after banana due to its dietary value and taste. The fastidious bacteria are responsible for the damages in this disease causing the destruction of vascular bundles in citrus plants. In the current research various DNA extraction protocols were compared to determine the best one in terms of obtaining the quality DNA. Because it is almost very difficult to get a highly stabile DNA by using the simple CTAB or SDS method. The subtropical or tropical and citrus spp. are perennial woody plants and therefore even their young tissues contain more Polysaccharide content than other field crops. The old DNA extraction procedures i.e. CTAB (Saghai-Maroof et al., 1984) and SDS (Dellaporta et al., 1983), were found inefficient to remove polysaccharides. Rather a minor change or amendment in the fundamental protocol gave a high-quality genomic DNA from the citrus leaves' midribs. In our research modified SDS and CTAB method gave high quality product for the amplification of the bacterial genome as it reduces the phenols and 
polysaccharides or completely remove the polysaccharides in the product. Although the changes made were not so drastic but simple variation in the protocol leads us to the quality DNA product (Fang et al., 1992, Möller et al., 1992, Porebski et al., 1997). CTAB method was modified by increasing the incubation time i.e., 45 minutes for cell lysis in water bath and by increasing the double amount of beta mercaptethanol for determination the variation in quality of DNA. With this treatment, polysaccharides concentrated in the interphase while the DNA still dissolved in the bottom aqueous phase. By discarding gel like interphase, we can get rid of polysaccharides.

We were able to amplify 16 s rDNA region of Candidatus liberobacter by utilizing 4 set of primers. The modifications adopted in CTAB method found a quick and efficient method for DNA extraction from citrus midrib tissues. So, this method can perform well for future molecular study involving large numbers of different plant samples. As a result of these modifications, we obtained pure and high-quality DNA suitable for further molecular analysis. Moreover, modified method reflects the competence of the protocol and proves its suitability for further analysis like PCR amplifications. In the current study, we optimized a modified SDS-based DNA extraction method and results was then compared to those extracted by old SDS method and DNA extraction kit. In this regard, we revealed that the Modified SDS method gave higher DNA yield and cell lysis more effectively, lower DNA shearing, and higher diversity scores than other two methods. The modified CTAB method was compared with extraction kit such as molequle on kit for genomic DNA from plants for PCRbased detection of HLB. Our comparative tests revealed that DNA which were extracted by modified methods contain low quantity of phenolic compounds. The modified extraction methods make DNA able for long term storage.

\section{CONCLUSION}

A good quality DNA can be obtained from citrus leaf midribs by making some amendments in normal protocols. Increase in the lysis time in water bath and by doubling the amount of beta mercaptethanol removes the high density of polysaccharides in the samples.

\section{ACKNOWLEDGMENTS}

The authors are thankful to farming community of citrus in Multan y facilitating us in obtaining the disease samples from their orchards.

\section{REFERENCES}

Bové, J., M. E. Dwiastuti, A. Triviratno, A. Supriyanto, E. Nasli, P. Becu and M. Garnier. 2000. Incidence of huanglongbing and citrus rehabilitation in North Bali, Indonesia. International Organization of Citrus Virologists Conference Proceedings (1957-2010).

Bové, J. M. 2006. Huanglongbing: a destructive, newlyemerging, century-old disease of citrus. Journal of plant pathology, 7-37.

Chung, K.R. and R. H. Brlansky. 2006. Citrus Diseases Exotic to Florida: Citrus Tristeza Virus, Stem Pitting. Plant Pathology Department, Florida Cooperative Extension Service, Institute of Food, pp. 210.

Coletta-Filho, H. D., M. L. P. N. Targon, M. A. Takita, J. D. De Negri, J. Pompeu, M. A. Machado, A. M. do Amaral and G. W. Muller. 2004. First Report of the Causal Agent of Huanglongbing ("Candidatus liberibacter asiaticus") in Brazil. Plant Disease, 88: 1382-1382.

de la Cruz, M., F. Ramirez and H. Hernandez. 1997. Plant Molecular Biology Reporter, 15: 319-325.

Dellaporta, S. L., J. Wood and J. B. Hicks. 1983. A plant DNA minipreparation: Version II. Plant Molecular Biology Reporter, 1: 19-21.

Deng, X., Y. Lan, T. Hong and J. Chen. 2016. Citrus greening detection using visible spectrum imaging and C-SVC. Computers and Electronics in Agriculture, 130: 177183.

Eveland, W. G. and K. E. Brown. 2019. Method of Treating Citrus Greening. Google Patents.

Fang, G., S. Hammar and R. Grumet. 1992. A quick and inexpensive method for removing polysaccharides from plant genomic DNA. Biotechniques, 13: 52-54.

Fraser, L. R. and D. Singh. 1968. Citrus dieback in Indiathe contribution of greening virus. International Organization of Citrus Virologists Conference Proceedings (1957-2010).

Fujikawa, T. and T. Iwanami. 2012. Sensitive and robust detection of citrus greening (huanglongbing) bacterium "Candidatus liberibacter asiaticus" by DNA amplification with new 16S rDNA-specific primers. Molecular and Cellular Probes, 26: 194197.

Garnier, M. 1983. Transmission of the Organism Associated with Citrus Greening Disease from Sweet Orange to Periwinkle by Dodder. Phytopathology, 73: 1358.

Garnier, M. and J. M. Bové. 1993. Citrus greening disease and the greening bacterium. International Organization of Citrus Virologists Conference 
Proceedings (1957-2010).

Gottwald, T. R. 1989. Preliminary Analysis of Citrus Greening (Huanglungbin) Epidemics in the People's Republic of China and French Reunion Island. Phytopathology, 79: 687.

Hong, Y., Y. Luo, J. Yi, L. He, L. Dai and T. Yi. 2019. Screening nested-PCR primer for 'Candidatus Liberibacter asiaticus' associated with citrus Huanglongbing and application in Hunan, China. PLOS ONE, 14: e0212020.

Jagoueix, S., J. M. Bove and M. Garnier. 1994. The PhloemLimited Bacterium of Greening Disease of Citrus Is a Member of the Subdivision of the Proteobacteria. International Journal of Systematic Bacteriology, 44: 379-386.

Jagoueix, S., J. M. Bové and M. Garnier. 1996. PCR detection of the two Candidatus liberobacter species associated with greening disease of citrus. Molecular and Cellular Probes, 10: 43-50.

Manjunath, K. L., S. E. Halbert, C. Ramadugu, S. Webb and R. F. Lee. 2008. Detection of 'Candidatus liberibacter asiaticus' in Diaphorina citri and Its Importance in the Management of Citrus Huanglongbing in Florida. Phytopathology, 98: 387-396.

Möller, E. M., G. Bahnweg, H. Sandermann and H. H. Geiger. 1992. A simple and efficient protocol for isolation of high molecular weight DNA from filamentous fungi, fruit bodies, and infected plant tissues. Nucleic Acids Research, 20: 6115-6116.

Planet, P., S. Jagoueix, J. M. Bov and M. Garnier. 1995. Detection and characterization of the African citrus greening Liberobacter by amplification, cloning, and sequencing of the rplKAJL-rpoBC operon. Current Microbiology, 30: 137-141.

Porebski, S., L. G. Bailey and B. R. Baum. 1997. Modification of a CTAB DNA extraction protocol for plants containing high polysaccharide and polyphenol components. Plant Molecular Biology Reporter, 15: 8-15.

Saghai-Maroof, M. A., K. M. Soliman, R. A. Jorgensen and R. W. Allard. 1984. Ribosomal DNA spacer-length polymorphisms in barley: mendelian inheritance, chromosomal location, and population dynamics. Proceedings of the National Academy of Sciences, 81: 8014-8018.

Schlink, K. and R. Reski. 2002. Preparing high-quality DNA from moss (Physcomitrella patens). Plant Molecular Biology Reporter, 20: 423-423.

Spreen, T. H., J.-P. Baldwin and S. H. Futch. 2014. An Economic Assessment of the Impact of Huanglongbing on Citrus Tree Plantings in Florida. HortScience, 49: 1052-1055.

Teixeira, D. d. C., C. Saillard, S. Eveillard, J. L. Danet, P. I. d. Costa, A. J. Ayres and J. Bové. 2005. 'Candidatus liberibacter americanus', associated with citrus huanglongbing (greening disease) in São Paulo State, Brazil. International Journal of Systematic and Evolutionary Microbiology, 55: 1857-1862.

Yaqub, M. S. 2017. Molecular detection of Candidatus liberibacter asiaticus, the causal organism of huanglongbing (citrus greening) in faisalabad, pakistan for huanglongbing management. Pakistan Journal of Agricultural Sciences, 54: 21-26.

\begin{tabular}{|lll|}
\hline Contribution of Authors: & & \\
Muhammad Nauman & $:$ & Conceived the research idea \\
Ummad U. D. Umar & $:$ & Supervised research \\
Syed A. H. Naqvi & $:$ & Conducted research trails \\
Ateeq U.Rehman & $:$ & Helped in research trails \\
Muhammad T. Malik & $:$ & Make tables \\
Muhammad Shahid & $:$ & Analyzed data \\
Muhammad Akbar & $:$ Wrote manuscript \\
Muhammad Umair & $:$ Helped in manuscript writeup \\
\hline
\end{tabular}

